\title{
Cytokine activity of the non-catalytic EMAP-2-like domain of mammalian tyrosyl-tRNA synthetase
}

\author{
Alexander Kornelyuk, Maarten P. R. Tas', Alexei Dubrovsky, J. Clifford Murray ${ }^{1}$ \\ Institute of Molecular Biology and Genetics, National Academy of Sciences of Ukraine \\ 150 Acad. Zabolotnoho vul., Kyiv, 252143, Ukraine \\ 'University of Nottingham Laboratory of Molecular Oncology, Cancer Research Campaign Department of Clinical Oncolugy \\ City Hospital, Nottingham NG.5 1PB, Great Britain
}

\begin{abstract}
Cytokine activity of the isolated recombinant C-terminal domain of mammaliat tyrosyl-tRNA synthetase (TyrRS), which is homologous to a tumor-derived cytokine, endothelial and monocyte activatins polypeptide (EMAP-2) has been studied. It was shown that $C$-domain induced $a-2$-jold increase of monocyte chemotaxis. This effect is comparable with the values of chemotaxis induction by EMAP- $\hat{2}$ cytokine and proEMAP-2. The truncated catalytic form of bovine TyrRS $(2 \times 39 \mathrm{kDa})$ has no effect on monocyte chemotaxis. $C$-domain of TyrRS also induced $a-3$-fold increase in tissuc factor activity in cultured human ehdothelial cells. A hypothesis is forwarded that the isolated $C$-domiain of mammalian TyrRS may be released at proteolytic cleavage of TyrRS by some protease, activated ui stress conditions, and functions as a mediator via signal transduction through interaction with a ju ative EMAP-2 recepic..
\end{abstract}

Introduction. Aminoacyl-tRNA synthetases (ARSases) of higher eukaryotes usually possess amino- and/or carboxy-terminal polypeptide extensions of catalytic enzyme core which are dispensable for their catalytic activities $[1-4]$. The functions of these extensions are related to the complex organization of protein synthesis apparatus of multicellular organisms. For example, some manmalian ARSases have abilities to form a multi-tRNA synthetase complex which includes 9 ARSases and 3 other auxiliary protein components $[1-3]$. On other hand, these appended domains could be responsible for the polyanion binding properties of eukaryotic ARSases and compartmentalization of components of protein synthesis machinery on the ribosomes $[4,5]$.

Recently the amino acid sequences of bovine and human TyrRS were determined $[6,7]$, revealing a high sequence homology $(51 \%$ identity) between the C-terminal, non-catalytic domain of TyrRS and the novel cytokine-like molecule endothelial-monocyteactivating polypeptide (EMAP-2) [6-8]. Previously, we have shown, that botine tyrosyl-tRNA synthetase $\left(\alpha_{2}\right.$-dimer, $\left.2 \times 59 \mathrm{kDa}\right)$ could be isolated from bovine

(C) A. I. KORNELYUX, M. F. R. TAS. A L. DLBROVSKY, liver both as the full-length protein and as a proteolytically-modified active enzyme form $(2 \times$ $\times 39 \mathrm{kDa}$ ), which lacks its $\mathrm{C}$-terminal polypeptide extension $[9,10]$. Both distinct molecular forms of TyrRS displayed the similar catalytic constants in tRNA aminoacylation reaction [9. 10]. Moreover, the dispensable C-terminal polypeptide extension of bovine TyrRS revealed a significant contribution to the non-specific affinity of this enzyme for RNA [11].

A novel putative cytokine, EMAP-2, modulates a variety of properties of endothelial cells, monocytes and leukocytes in vitro, and induces an acute inflammatory reaction in vivo $[12,16]$. Based on the sequence similarity of mammalian TyrRS C-domain and EMAP-2, we have forwarded the hypothesis that the isolated C-domain may also display the cytokine activity, similar to EMAP-2 cytokine [8 ]. In order to verify this hypothesis we have cloned and expressed the isolated non-catalytic C-terminal domain of bovine TyrRS [17].

In this work we have discovered several cytokinelike activities of the isolated C-domain of TyrRS in vitro which are compared with the properties of recombinant EMAP-2 cytokine.

Materials and Methods. Proteins isolation. Clo- 
ning and bacterial expression of the C-terminal domain of bovine TyrRS was performed as described earlier [17]. The BamHI cDNA fragment encoding residues D.322-S528 of bovine TyrRS was cloned into the $p E T 15 \mathrm{~h}$ vector for bacterial expression and recombinant protein was expressed in BL21(DE3) Escherichia coli cells harboring the pEYCD2 plasmid. The supernatant was loaded onto Ni-NTA column and $6 \mathrm{His}$-tagged recombinant protein was eluted with $300 \mathrm{mM}$ imidazole.

Recombinant human EMAP-2 and proEMAP-2 were isolared and characterized as previously described [18].

Monocyte chemotaxis: Freshly-isolated monocytes were then suspended in RPMI-1640 medium with $10 \%$ foctal calf serum, at $2 \times 10^{6}$ cells per ml. Solutions of proteins (TyrRS C-domain, $39 \mathrm{kDa}$ TyrkS and EMAP-2) or chemotactic peptide, formylmethionyl-leucyl-phenyalanine (fMLP) $(31 \mu \mathrm{l})$ at the indicated concentrations were placed in the bottom wells of Chem Tx micro-chemotaxis plates (Neuro Probe, Inc.) in triplicate. The filter was placed on top of the solution in such a way as to provide fluid continuity between the upper and lower chambers. An aliquot of monocyte suspension $(27 \mu 1)$ was then placed on top of the filter above each well, and the plates incubated with lids on for $1.5 \mathrm{hr}$ at $37{ }^{\circ} \mathrm{C}$ in air $/ 5 \% \mathrm{CO}_{2}$. After incubation, cells binding to the membrane were fixed by the addition of $15 \mu \mathrm{l}$ of ice-cold $20 \%$ formaldehyde in phosphate-buffered saline, and those that had migrated to the underside of the membrane were counted with a haemocytometer.

Procoagulant activity assay: Human umbilical vein endothelial cells (HUVEC) were isolated essentially by the method of Jaffe et al. [19]. Confluent endothelial monolayers at passages 2 to 3 were used to assess tissue factor-dependent procoagulant activity [20]. Coagulation was initiated by the addition of 100 $\mu 1$ of $30 \mathrm{mM} \mathrm{CaCl} 2$ solution at $37^{\circ} \mathrm{C}$ and the time for visible fibrin strand/gel formation was determined. Procoagulant activity of endothelial monolayers was expressed as tissue factor equivalents (TFE, $\mathrm{pg} / 10^{\circ}$ cells) [20].

Results and Discussion. Purification of recombinant C-domain of TyrRS, expressed in $E$. coli cells after induction by IPTG and containing a $6 \mathrm{His}$-tag, has been performed by metal-chelation chromatography. According to gel-electrophoresis data, the homogeneity of recombinant protein was about $95 \%$ [17].

Since EMAP-2 cytokine has been shown to induce migration of monocytes and polymorphonuclear leukocytes in vitro $[12,18]$, we therefore examined the effects of TyrRS C-domain on monocyte migration, using a micro-chemotaxis chamber assay. The addition of TyrRS C-domain to the lower chamber led to a $\sim 2$-fold enhancement of monocyte migration (Fig. 1). Monocyte migration was induced by $\mathrm{C}$ domain in the range $1 \mathrm{pM}-10 \mathrm{nM}$ (between $1 \mathrm{pM}$ and $100 \mathrm{pM}$ this increase was significant, $p<0.05$ ) at levels slightly greater than that induced by recombinant EMAP-2 over a similar concentration range, but not as high as those achieved with $10 \mathrm{nM}$ control chemotactic peptide fMLP. In contrast to isolated C-domain, the truncated $39 \mathrm{~K}$ form of mammalian TyrRS, which lacks this domain, did not affect monocyte migration (Fig. 1).

A defining biological activity of EMAP-2 is its ability to induce tissue-factor-dependent procoagulant activity on the surface of endothelial cells in vitro, and furthermore to potentiate procoagulant activiity induced by tumour necrosis factor (TNF) in vitro [12]. Therefore we studied the abilities of TyrRS C-domain and EMAP-2 polypeptide to induce tissue factormediated procoagulant activity on the surface of cultured HUVEC.

The exposure of endothelial cells to isclated C-domain for $4 \mathrm{hr}$ at concentrations of $1-100 \mathrm{pM}$ led to a dose-dependent increase in cell surface tissue factor between 0.36 and $0.77 \mathrm{pg}$ TFE $/ 10^{6}$ cells on endothelial cells (Fig. 2,a). EMAP-2 also induced the enhancement of tissue factor activity in a dose-dependent manifer (Fig. 2, b), but maximum activity was observed at lower mediator concentration at about $1 \mathrm{pM}$.

Our data suggest that the isolated $\mathrm{C}$-domain of mammalian TyrRS reveals cytokine-like activities both as a chemotactic factor for monocytes and as an inducer of tissue factor expression on human endothelial cells sinilar to EMAP-2 cytokine. We propose, therefore, that the C-domain of TyrRS could potentially mimic the action of EMAP-2 cytokine through the interactions with complementary sites on the specific receptor.

Moreover, the cellular effects of TyrRS C-domain that we have observed, in particular the induction of tissue factor activity, cannot be fully explained by in interaction of its $\mathrm{N}$-terminal region with a receptor. As indicated earlier, the chemotactic and tissue factor-inducing activity of EMAP-2 are believed to reside within different regions of the molecule [14]. Since we have also observed tissue factor induction in response to the TyrRS C-domain, it is possible that other functional domains of this C-terminal module, except its $\mathrm{N}$-terminal region, could be involved in its cytokine activities.

If the EMAP-2-like domain of TyrRS is released 


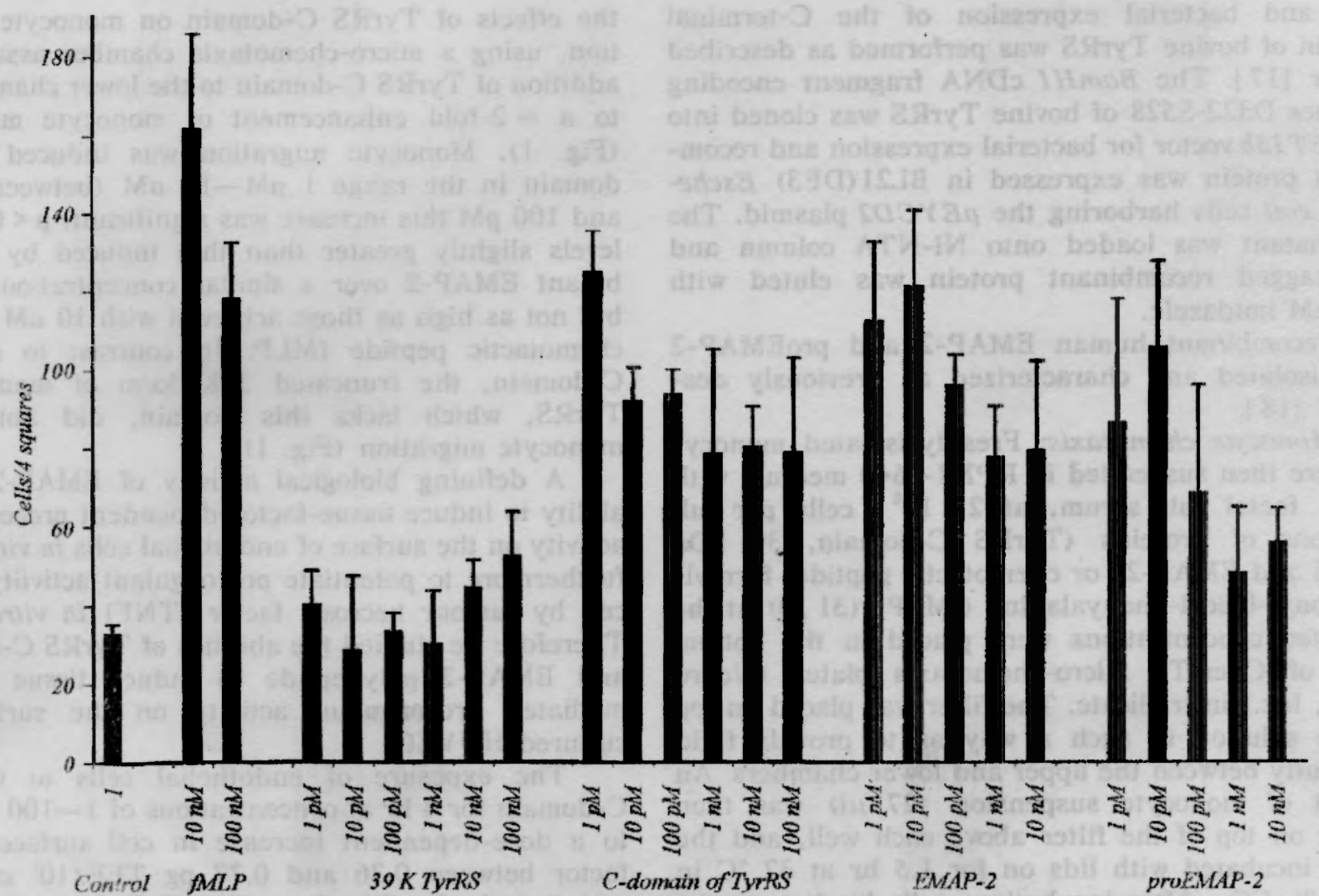

Fig. 1. Induction of monocytes migration by recombinant C-domain of TyrRS and EMAP-2 proteins as studied by micro-chemotaxis chamber assay. Cell migration assays were performed as described under «Materials and Methods». Data shown the standard deviations estimated with medium alocie control. Chemotactic peptide fMLP was used as a positive control


Fig. 2. Induction of procoagulant activity of tissue factor in human endothelial cells by recombinant C-domain of TyrRS $(A)$ or EMAF-2 cytokine $(B)$. Results are the means of 6 replicates pooled from 2 separate experiments 
after proteolytic cleavage at the loop, connecting the catalytic $39 \mathrm{kDa}$ enzyme core and this $\mathrm{C}$-domain, it could be involved as a mediator in signal transduction process through the interactions with a putative EMAP-2 receptor. The nature of the EMAP-2 receptor is not known, although cross-linking studies have demonstrated binding of EMAP-2-derived peptides to a $73 \mathrm{~K}$ protein associated with the monocyte cell surface [21], suggesting the existence of a distinct receptor.

Recently, it was shown that in cultured cells post-translational processing of proEMAP-2 into mature cytokine EMAP-2 occurred coincidentally with apoptosis programmed cell death [22]. It is well known that during apoptosis process some proteases, e. g. interleukin-1 converting enzyme (ICE, caspase) are activated [22]. It is possible to propose, that mammalian TyrRS could be cleaved during apoptotis proteolytic cascade, or other protease activation process.

It is interesting to note, that other component of protein biosynthesis machinery, auxiliary $\mathrm{p} 43$ protein of multi-synthetase complex, is proposed to be a precursor of EMAP-2 cytokine [23].

Our results suggest a novel non-canonical function of mammalian aminoacyl-tRNA synthetases in higher eukaryotic cells, which may be associated with signal transduction process. Furthermore this function may only be expressed in conditions where cellular proteases are activated.

Acknowledgements. This work was supported by the Cancer Research Campaign and by a Wellcome Trust Travel Grant to A. I. K.

\section{О. І. Корнелюк, М. Тас, О. Л. Дубровський, Дж. К. Мюррей}

Цитокінова активність некаталітичного ЕМАР-2-подібнопо домена тирозил-тРНК синтетази ссавців

\section{Резоме}

Досліджено цитокінову активність ізольованого рекомбінант ного С-кінцевого домена тирозил-тРНК синтетази (тирРС) ссавців, гомологіиного ЕМАР-2 цитокіну. Показано, що С-домен індукує збільиення хемотаксису моночитів у 2 рази. Цей ефект близький до такого, спричиненого ЕМАР-2 та ргоЕМАР-2. Протеолітично модифікована каталітична форма тирРС $(2 \times 39 \kappa Д а)$ не впливала на хемотаксис моноцитів. С-домен тирРС також індукує зростання активності тка нинного фактора ендотеліальних клітин людини в 3 рази. Пропонутьься zіпотеза стосовно того, що ізольований С-домен може вивільнятися при протеалітичному розщепленні тирРС певною протеазою, яка активується в стресових умпвах, і функціонувати як медіатор иляхом передачі сигналу при взаємодії з рецептором ЕМAP-2 цитокіну.

\section{А. И. Корнелюк, М. Тас, А. Л. Дуброзский, Дж. К. Мюрией}

Цитокиновая активность некаталитического ЕМАР-2-подобного домена тирозил-тРНК синтетазы млекопитающих:

Резюме

Изучена иитокиновая активность изолированяого рекомбі: нантного С-концеяого домена тирозил-тРНК синтета:зы (тирРС) млекопитающих, сомологинного ЕМАР-2 цитокигу. Показано, что С-домеи индуцирует увеличение хемотаксиса моноцитов в 2 роза. Этот әффект близок к макозому, вызываемому ЕМАР-2 " ргоЕМАР-2. Пратеолитически моdифицированная каталитическая форла тирРС $(2 \times 39 \kappa\{a)$ не влияет на хемопаксис моноиитов. С-домен тирРC также индуцирует рост актизности тканевого фиктора эндоме лиильных клеток иеловека в 3 раза. Предложена гипотеза отиосительно того, ито изолированный С-домен может высєобождаться при протеолитическом расщепленик тирРС определюной протеазой. актияируелій з стрегсовых условияла, и функционировать как медиапор путем передачи сиснала при взинмодействии с рецентором цитокина ЕMAP-2.

\section{REFERENCES}

1. Mirande $M$. Amincacyl-tRNA synthetase family from pro. karyotes and eukaryotes. Structural domains and their implications // Progr. Nucl. Acid Res. Mot. Biol.-1991.-40.P. 95-142.

2. Kisselev $L . L$, Wolfson A. D. A mincacyl-tRNA syntheta:es from higher eukaryotes // Progr. Nucl. Acid Res. Mo. Biol. -1994.-48.-P. 83-141.

3. Rho S. B., Lee K. I., Kim J. W., Shiba K., Jo Y. J., Kim S. Interaction between human IRNA synthetases involves repeated sequence elements // Froc. Nat. Acad. Sci. USA.-1996.93.-P. $10128-10133$.

4. Cirakoglu B., Waller J.-P. Do yeast aminoacyl-tRNA sy 3thetases exis: as; «soluble enzymes within the cytoplasm? /i Eur. J. Biochem. - 1985 - 1 49.-P. 353--361.

5. Ryazanov A. G., Ovchinnikov L. P., Spirin A. S. Devel pment of structural organization of protein-synthesing machinery from prokaryotes to eukaryotes // Biosystems. - 1987.--20.P. $275-288$

6. Levanets $O$. V., Naidenov V. G., Woodmaska M. I., Matsuka $G$. H., Kornclyuk A. I. Cloning of cDNA encoding C-terminal part of mammalian tyrosyl-tRNA synthetase using of $\mathrm{PCR}$ amplified radioactive probe // Biopolymeri i kletka (Kyiv)..1997.-13.-P. $121-126$

7. Kleeman T. A., Wei D. B., Simpson K. L., First E. A. Human tyrosyl tRNA synthetase shares amino acid sequence hornology with a putative cytokine // J. Biol. Chem. $-1997,-272 .-$ P. $14420-14425$

8. Levanets $O . V$. , Naidenov V. G., Odynets $K$. A., Woodmasica M. I., Matsuka G. Kh, Kornelyuk A. I. Ilomology of C-terminal noncatalytic domain of mammalian tyrosyl-tRNA synthetase with cytokine EMAP II and noncatalytic domains of methionyl- and phenylalanyl-tRNA synthetases /i Biopolym ri i kletka (Kyiv) .-1997.-13.-P. 47.4-478.

9. Kornelyuk A. I., Kurochkin I. V., Matsuka G. Kh. Bovine liver tyrosyl-tRNA synthetase. Isolation and physico-chemical pro. perties // Mol. Biol. (Moscow).-1988.-22.-P. 176-186.

10. Gnatenko D. V., Kurochkin I. V., Ribkinska T. A., Korrelyuk, A. I., Matsuka G. Kh. Purification and characterization of functionally active proteolylically modified form of tyrosyltRNA synthetase from bovine liver // U/k: Biokhim. ?hurk. (Kyiv).-1991.-63-P. 61-67.

11. Kurochkin I. V., Kornelyuk A. I., Matsuka G. Kh. Interaction of eukaryotis ty'rosyl-tRNA synthetases with high molecular 
weight RNAs // Mo'. Biol. (Moscow)._1991.-25._P. 632638.

12. Kao J., Ryan J., Brett G., Chen J., Shen H., Fan Y., Godman G., Familletti P. C., Wang F., Pan Y. E., Stern D., Clauss $M$. Endothelial monocy te-activating polypeptide II. A novel tumorderived polypeptide that activates host-response mechanisms // J. Biol. Chem.-1992.-267. -P. 20239-20247.

13. Kao J., Houck K., Fan Y., Haehnel I., Libutti S. K., Kayton M. L., Grikscheit T., Chabot J., Nowygrod R., Greenberg S., Kuang W.-J., Leung D. W., Hayward J. R., Kisiel W., Heath $M$. Brett J., Stern D. $M$. Characterization of a novel tumor-derived cytokine. Endothelial monocyte-activating polypeptide II // J. Biol. Chem. - 1994. - 269.-P. 2510625119

14. Kao j., Fan Y.-G., Haehnel I., Brett J., Greenberg S., Clauss $M$, Kayton M., Houck $K$, Kisiel W., Seljelid R., Burnier J., Stern $D$. A peptide derived from the amino terminus of endothelial-monocyte-activating polypeptide II modulates mononuclear and polymorphonuclear leukocyte functions, defines an apparently novel cellular interaction site, and induces an acute inflammatory response // J. Biol. Chem. - 1994.-269.P. 9774-9782.

15. Singer I. f., Scott S., Chin J., Bayne E. K., Limjuco G., Weidner J., Miller D. K., Chapman K., Kostura M. J. The inlerleukin-1b-converting enzyme (ICE) is localized on the external cell surface membranes and in the cytoplasmic ground substance of human monocytes by immuno-electron microscopy // J. Exp. Med.-1995.-182-P. 1447-1459.

16. Tas $M$. P., Murray J. C. Endothelial-monocyte-activating polypeptide II // Int. J. Biochem. Cell. Biol-1996.-28.P. 837-841.

17. Dubrovsky A. L, Savinskaya L. A, Kornelyuk A. I. Cloning and bacterial expression of the cytokine-like noncatalytic domain of bovine tyrosyl-tRNA synthetase // Biopolimeri i kletka (Kyiv).-1998.-14.-P. 449-452.
18. Tas M. P. R., Houghton J., Jakobsen A. M., Tolmachova T., Carmichael J., Murray J. C. Cloning and expression of human endothelial-monocyte-activating polypeptide 2 (EMAP-2) and identification of its putative precursor // Cytokine. - 1997... 9.-P. 535-539.

19. Jaffe E. A. Nachman R. L., Becker C. G., Mindi C. R. Culture of human endothelial cells derived from umbilical veins: identification by morphological and inmunological criteria $/ / 3$. Clin. Invest -1 973.-52.-P. 2745-2756.

20. Murray J. C., Clauss M., Denekamp J., Stern D. Selective induction of endothelial cell tissue factor in the presence of a tumour-derived mediator: a potential mechanism of flavorie acetic acid action in tumour vasculature // Int. J. Cancer1991.-49.-P. $254-259$.

21. Knies U. E., Behrensdorf H. A., Mitchell C. A., Deutsch U., Risau W., Drexler H. C. A., C auss $M$. Regulation of endothelial monocyte-activating polypeptide II release by apoptosis // P'roc. Nat. Acad. Sci. USA..-1998.-95P. 12322-123:7.

22 Marvin M. R., Libutti S. K., Kayton M., Kao J., Hayward J., Grikscheit T., Ian Y., Brett J., Weinberg A., Nowygrod R., LoGerfo P., Feind C., Hansen K., Schwarz M., Stern D., Chabot $J$, A novel tumor-derived mediator that sensitizes cytokine-resistant tumors to tumor necrosis factor // J. Surg. Res.-1996.-63.-P. 248-255.

23. Quevillon S., Agou F., Robinson J. C., Mirande M. The 1443 component of the mammalian multi-synthetase complex us likely to be the precursor of the endothelial monocyte-activating polypeptide II cytokine // J. Biol. Chem..-1997._-272.P. 32573-325\%9.

YIIK 577.152.611 Received 23.11.98 